\title{
Oak wood degradation processes induced by the burial environment in the archaeological site of Biskupin (Poland)
}

\author{
Jeannette Jacqueline Lucejko ${ }^{1}$, Diego Tamburini ${ }^{1,4}$, Magdalena Zborowska² ${ }^{2}$ Leszek Babiński \\ Francesca Modugno ${ }^{1}$ and Maria Perla Colombini ${ }^{1 *}$ (1)
}

\begin{abstract}
The open-air Archaeological Museum in Biskupin (Poland) preserves and shows to the public a prehistoric settlement of Lusatian culture dating back to Early Iron Age (eighth century BC). The monitoring of the environment and dynamics of the wood degradation in the burial conditions at the site is fundamental for the in situ preservation of archaeological wooden materials. A monitoring program thus started in 2003 at the Biskupin site, using contemporary sound oak wood that was placed in two wet burial environments, characterised by different conditions. A multi-analytical protocol was exploited to obtain information on the structural, physical and chemical conditions of the buried wood. The study involved the application of gravimetric and wet chemical analysis, and instrumental techniques, including infrared spectroscopy (FTIR) and analytical pyrolysis (Py-GC/MS) to evaluate alterations in the buried oak wood over a 10-year period. The results showed that, during the burial period in both monitoring stations, there was only limited chemical transformation of the polysaccharide component, mostly involving hemicelluloses. The differences observed might be due to the natural compositional variability and inhomogeneity of oak wood. The final condition of the wood was very similar in the two burial environments. It is therefore suggested that the wet burial conditions in the Biskupin site represent a safe conservation environment for the in situ preservation of the wood remains, at least those presenting a good initial preservation state. This supports the conservation strategy adopted in the Biskupin Museum site.
\end{abstract}

Keywords: Natural ageing, Wood degradation, Depolymerisation, Monitoring program, Biskupin

\section{Introduction}

Excavating and then conserving archaeological remains is not the only possible approach for their preservation. In fact, in situ preservation is an increasingly common alternative [1-3]. The storage and protection of fragile and non-renewable archaeological findings, namely in situ preservation, emerged as highly relevant at the UNESCO Convention [4], where it was stated that in situ storage of

\footnotetext{
${ }^{*}$ Correspondence: maria.perla.colombini@unipi.it

${ }^{1}$ Department of Chemistry and Industrial Chemistry, University of Pisa, via

G. Moruzzi 13, 56124 Pisa, Italy

Full list of author information is available at the end of the article
}

archaeological remains in natural environments plays an important role in preserving humanity's cultural heritage.

In situ preservation of archaeological remains requires a regular monitoring of the conditions of the buried material, as well as the limitation and/or reduction of the impact and risk caused by the burial conditions.

For what concerns the preservation of waterlogged wooden archaeological artefacts, one of the best known examples of in situ preservation is the archaeological site of Biskupin (Poland), where the wooden remains of a settlement of Lusatian culture dating back to the Early Iron Age (eighth century $\mathrm{BC}$ ) are preserved [5]. The site was discovered in 1933 [6]. At the end of the excavation
Springer Open

(c) The Author(s) 2020. This article is licensed under a Creative Commons Attribution 4.0 International License, which permits use, sharing adaptation, distribution and reproduction in any medium or format, as long as you give appropriate credit to the original author(s) and the source, provide a link to the Creative Commons licence, and indicate if changes were made. The images or other third party material in this article are included in the article's Creative Commons licence, unless indicated otherwise in a credit line to the material. If material is not included in the article's Creative Commons licence and your intended use is not permitted by statutory regulation or exceeds the permitted use, you will need to obtain permission directly from the copyright holder. To view a copy of this licence, visit http://creativeco mmons.org/licenses/by/4.0/. The Creative Commons Public Domain Dedication waiver (http://creativecommons.org/publicdomain/ zero/1.0/) applies to the data made available in this article, unless otherwise stated in a credit line to the data. 
campaigns in 1974, an in situ conservation strategy was implemented.

Wet conditions allow for the preservation of wood for a long period of time, due to the low temperatures and low oxygen concentrations limiting attacks from fungi and insects, and absence of light. Several important archaeological wood artefacts have indeed been recovered from waterlogged conditions in a relatively good-at least apparent-preservation state, such as the shipwrecks of the Roman ships of San Rossore [7], the warship Vasa in Stockholm [8], the Mary Rose in Portsmouth [9], and the Bremen Cog in Germany [10].

However, degradation of wood occurs to some extent in abiotic environment, due to the action of the water and to anoxic biological agents. A further risk is associated with human activities: since excavations started in Biskupin, and because of climate changes, alterations in the burial environment have occurred, such as the lowering of the ground water level and the aeration of the soil. These phenomena accelerate wood degradation and make it necessary to investigate the dynamics of the environmental changes. To address this issue, in 1991, a groundwater level monitoring system was set up in Biskupin [11], and a barrier was constructed in 1992, with the result that the water level was increased by several centimetres [12].

Assessment of the state of preservation of wooden artefacts is fundamental in this context and the present state of the art generally includes physical [13], morphological [14] and chemical characterisations [15-18]. The first approach to evaluate the conditions of the wooden structural elements from the Biskupin site was limited to assessing their integrity as a building material (e.g., the presence of bark) or a component of a larger construction, and to describing the surfaces of the objects under examination-visible signs of processing or damage [19]. According to the first macroscopic observations, the preservation state of the Biskupin wood was described as "good". Physical, mechanical and structural features of wood were investigated after the Second World War [20]. Subsequently, investigations into the degradation processes caused by microorganisms was performed by Ważny, who also described the irreversible structural changes caused by the excavation and drying of archaeological wooden artefacts [21]. Recent studies have shown that the wooden remains kept underground are in a very good condition from the point of view of chemical composition [22].

In 2003, an interdisciplinary research project was set up to monitor the environmental conditions and the dynamics of the degradation of the buried wood in the archaeological site of Biskupin. Selected parameters describing the environment where the wood was buried were measured: ground-water level, water conductivity, acidity $(\mathrm{pH})$ and soil redox potential [11]. It was observed that the monitored parameters fluctuated over the year due to seasonal changes. Periodic changes were also linked to polluted water from Lake Biskupin, derived from communal waste as well as pesticides or fertilizers. Moreover, precipitation (dissolved oxygen), changes in soil temperature, and the activity of many microorganisms could change the site conditions [23]. During the same year, samples of sound pine and oak wood and archaeological oak wood were buried in two different locations of the site (a peat deposit and a trench filled with water) [24]. Portions of the buried sound wood were taken from the two burial sites and analysed after 2, 4, 6, 8 and 10 years.

The first results of this program regarded bacterial and fungal microflora in oak wood [23]. Near infrared spectroscopy was used to analyse the pine and oak wood after short-term burial [25]. Parallel experiments were performed to study the changes occurring in the sound pine wood after burial when attacked by brown rot fungi in laboratory conditions [26]. Morphological studies by scanning electron microscopy (SEM) were performed on both pine and oak wood [27]. The SEM images clearly showed unaltered and intact cell structures after 2 years, and the detachment of the secondary cell wall was evident only after 10 years of burial. A clear trend of decay from 2 to 10 years of burial was not observed, but signs of soft rot fungi and bacteria attack were sporadically present and appeared to be the main causes of wood degradation in the burial sites.

Taking into consideration the results previously obtained, the aim of the present paper is to focus on the extent and the dynamics of the degradation processes which occurred in the oak wood involved in the monitoring. In fact, only pine wood was analysed with a similar protocol in a previous set of experiments [26]. Oak wood, particularly the heartwood, is considered one of the most durable against microbial agents among the European wood species [28]. Thus, the research here described completes the data on the monitoring program in Biskupin, presenting for the first time the results of the analysis of the buried oak wood obtained by a multi-analytical protocol. This protocol includes determination of physical properties, wet chemical analysis, Fourier transform infrared spectroscopy (FTIR) and analytical pyrolysis coupled with gas chromatography and mass spectrometry (Py-GC/MS). The approach was selected on the basis of previous experience with pine wood [26] and taking into account the need to obtain information at different levels, from the macro to the molecular one, in order to produce an overall picture. 


\section{Materials and methods Samples}

The research was carried out on samples of sound oak wood (Quercus sp.) which had been buried at the Biskupin site for 10 years [24]. The samples were cut out from the trunk of a 68-year-old oak tree (from the mature heartwood zone between annual increments 29 and 56) in 2003. The mean annual ring width was $1.81 \mathrm{~mm}$ (standard deviation $\mathrm{SD}=0.78 \mathrm{~mm}$ ), and the mean percentage of latewood was $62.6 \%(\mathrm{SD}=13.3 \%)$. A total of 440 wood samples (22 sets of 20 samples each) were used during the monitoring program. Their dimensions were $10 \mathrm{~mm}$ (radial) $\times 10 \mathrm{~mm}$ (tangential) $\times 150 \mathrm{~mm}$ (longitudinal).

Before burying them in the natural environment at the Biskupin site, the prepared wood samples were soaked for $4 \mathrm{~h}$ in water at a pressure of $50 \mathrm{hPa}$ in a vacuum chamber, and then at an atmospheric pressure for $20 \mathrm{~h}$, as described in [29]. Of the 22 prepared sample sets, 10 were mixed with wet peat, and 10 were mixed with sediment taken from the bottom of an archaeological trench filled with water, packed into a plastic mesh, and buried at $1 \mathrm{~m}$ depth in two monitoring stations: the first 10 sets in the monitoring station SP1, corresponding to a peaty environment, and the second 10 sets in the monitoring station SP4, corresponding to a water environment at the bottom of the sediment layer of a water-filled archaeological trench. The choice of the monitoring stations was dictated by the need to reproduce the burial conditions found upon the original discovery of the settlement.

The two remaining sample sets were used as control sets. Every 2 years from the burial, i.e. after 2, 4, 6, 8 and 10 years, two sample sets were collected from both monitoring stations. One set from each station was analyzed to determine the physical properties and mass loss of wood, and the other set was used to analyze chemical changes. The physical properties and chemical composition (wet chemical analysis) of the examined wood were determined immediately after the recovery of each sample set. After drying, the samples were stored in sealed and dark plastic boxes at $4{ }^{\circ} \mathrm{C}$ in plastic bags, in order to minimize the contact with external agents, until 2013-2014, when instrumental analyses were performed. Although the visual appearance of the samples after storage was not different, it is important to notice that chemical changes can occur during the storage period. For this reason, FTIR tests were performed twice on control samples, in the 1st year of the experiment and after 10 years of storage. The results obtained were the same; therefore it was assumed that there were no significant changes in wood composition during its storage for 10 years. SEM was also performed on the samples before instrumental analysis and major post-burial degradation signs were not observed.

During the burial period, some of the parameters related to soil and water were measured at the monitoring site [30]. The mean $\mathrm{pH}$ values for the water from the wet peat at SP1 were close to neutrality (6.8-7.2), whereas the water from the trench at SP4 was slightly more alkaline (7.6-7.8) due to the alkaline reaction of lake water (8.0-8.5). The conductivity of water from wet peat at SP1 $\left(960-1890 \mu \mathrm{S} \mathrm{cm}^{-1}\right)$ was higher than the conductivity of water from the archaeological trench at SP4 $\left(550-1190 \mu \mathrm{S} \mathrm{cm}^{-1}\right)$ and of the lake water (730$1380 \mu \mathrm{S} \mathrm{cm}^{-1}$ ), due to a higher concentration of salts in the soil than in the water. Peat temperature during summer, at a depth of $100 \mathrm{~cm}$, ranged from 16 to $17^{\circ} \mathrm{C}$, while during winter from 1 to $2{ }^{\circ} \mathrm{C}$. The mean redox potential of SP1 ranged from -180 to $-140 \mathrm{mV}$ and the mean redox potential of SP4 ranged from -180 to $-120 \mathrm{mV}$. These conditions are considered favourable for the preservation of wood components [30].

\section{Methods}

The level of degradation of buried wood samples after 2, 4, 6, 8 and 10 years at the Biskupin archaeological site was determined on the basis of:

- Physical properties, i.e. maximum water content (MWC), basic density (BD), wood porosity (P) and mass loss (ML);

- Chemical composition determined by three independent methodologies:

i. Classical wet chemical analysis;

ii. Infrared spectroscopy (FT-IR);

iii. Analytical pyrolysis coupled with gas chromatography and mass spectrometry (Py-GC/ MS).

\section{Physical properties and mass loss of wood}

The wood samples assigned for testing the physical properties and mass loss, after excavation from the archaeological site, were cleaned of residual peat and then treated with water, first for $4 \mathrm{~h}$ at $50 \mathrm{hPa}$ in a vacuum chamber and then at atmospheric pressure for $20 \mathrm{~h}$ to obtain the MWC. Impregnation under vacuum is not suitable for degraded archaeological wood [31], however in this case it was deemed appropriate as the examined wood was either sound or only slightly degraded. The procedure was repeated 10 times. The weight of the waterlogged samples was recorded both in air and in water. The determination of masses of dry wood samples was performed 
in air after drying to a constant mass at $103{ }^{\circ} \mathrm{C}$ in the oven. These masses were used to calculate: (i) maximum water content (MWC); (ii) basic density (BD); (iii) wood porosity (P); (iv) mass loss (ML), according to the following formulas:

$$
\mathrm{MWC}=100\left(\mathrm{~m}_{\mathrm{w}}-\mathrm{m}_{\mathrm{d}}\right) / \mathrm{m}_{\mathrm{d}}
$$

where MWC is the maximum water content (\%), $\mathrm{m}_{\mathrm{w}}$ is the mass of the waterlogged sample $(\mathrm{g})$, and $\mathrm{m}_{\mathrm{d}}$ is the mass of the oven-dry sample (g)

$$
\mathrm{BD}=\mathrm{m}_{\mathrm{d}} / \mathrm{V}_{\mathrm{w}}
$$

where BD is the basic density $\left(\mathrm{kg} \mathrm{m}^{-3}\right), \mathrm{m}_{\mathrm{d}}$ is the mass of the oven-dry sample $(\mathrm{kg})$, and $\mathrm{V}_{\mathrm{w}}$ is the volume of the waterlogged sample $\left(\mathrm{m}^{3}\right)$

$$
\mathrm{P}=100\left(\left(\mathrm{~m}_{\mathrm{w}}-\mathrm{m}_{\mathrm{d}}\right) / \mathrm{V}_{\mathrm{w}} \mathrm{d}_{\mathrm{w}}-0.028 \mathrm{~m}_{\mathrm{d}} / \mathrm{V}_{\mathrm{w}} \mathrm{d}_{\mathrm{w}}\right)
$$

where $\mathrm{P}$ is porosity (\%), $\mathrm{m}_{\mathrm{w}}$ is the mass of the waterlogged sample $(\mathrm{g}), \mathrm{m}_{\mathrm{d}}$ is the mass of the oven-dry sample $(\mathrm{g})$, and $\mathrm{V}_{\mathrm{w}}$ is the volume of the waterlogged sample $\left(\mathrm{cm}^{3}\right), \mathrm{d}_{\mathrm{w}}$ is the water density $\left(\mathrm{g} \mathrm{cm}^{-3}\right)$

$$
\mathrm{ML}=100\left(\mathrm{~m}_{0}-\mathrm{m}_{1}\right) / \mathrm{m}_{0}
$$

where $\mathrm{ML}$ is the mass loss (\%), $\mathrm{m}_{0}$ is the mass of the ovendry sample before burial on the site $(\mathrm{g})$, and $\mathrm{m}_{1}$ is the mass of the oven-dry sample after burial at the site $(\mathrm{g})$.

\section{Chemical composition}

All the samples were ground using a laboratory mill (Pulverisette 15, Fritsch GmbH, Germany). The sawdust fraction $(0.5-1.0 \mathrm{~mm})$ of wood was used for classical wet chemical analysis. For the Py-GC/MS and FT-IR analyses, further grinding was carried out on a zirconium oxide ball mill (Pulverisette 23, Fritsch GmbH, Germany). Before Py-GC/MS and FT-IR analysis, the removal of the residual water was necessary by drying the sample at $40-50{ }^{\circ} \mathrm{C}$ for $24 \mathrm{~h}$ in the oven.

Classical wet chemical analysis: a series of standard methods, which are recognised as also being applicable to archaeological degraded wood [18, 32, 33], were used to determine the weight contribution of each single wood component. T 222 om-06 standard of Technical Association of the Pulp and Paper Industry (TAPPI) method [34] was used to determine the lignin content. The cellulose content was measured by the Seifert method [35]. The content of water-soluble extractives was determined by the T $204 \mathrm{~cm}-07$ standard method, and ash content by the T 211 om-07 method [36, 37]. Each procedure was repeated three times for each sample set. The holocellulose content was calculated as the complement to $100 \%$ of the sum of the results obtained for lignin, extractives and ashes [38].

Infrared spectroscopy: A Thermo Fischer FT-IR Nicolet iS50 spectrometer was used in attenuated total reflection (ATR) mode. A total of 64 scans were carried out with a $4 \mathrm{~cm}^{-1}$ resolution in the range between 4000 and $400 \mathrm{~cm}^{-1}$. The samples were analyzed in triplicate. The baselines at 1730, 1503 and $897 \mathrm{~cm}^{-1}$ were constructed between 1774-1692, 1530-1484 and 911-878 $\mathrm{cm}^{-1}$, respectively. The results were averaged for three replicates. The standard deviation for the values obtained was always 0.1 or below.

Analytical pyrolysis: Py-GC/MS was performed in the presence of a silylation agent, 1,1,1,3,3,3-hexamethyldisilazane (HMDS, 99.9\%, Sigma Aldrich). The Py-GC/MS system was composed of a Multi-Shot Pyrolyzer EGA/ Py-3030D (Frontier Lab), an Agilent 6890 Gas chromatograph and an Agilent 5973 quadrupole Mass Selective Detector operating in electron impact mode (EI) at $70 \mathrm{eV}$. The temperature of the micro-furnace pyrolyzer was $550{ }^{\circ} \mathrm{C}$. A sample amount around $70 \mu \mathrm{g}$ with $2 \mu \mathrm{l}$ of HMDS was used. Other GC/MS instrumental parameters are described in the literature [22].

The peaks in the chromatographic profiles were assigned using the libraries Wiley and NIST and comparing with the literature [39]. For each sample, the peak areas of the pyrolysis products listed in Table 1 were integrated using the Automated Mass Spectral Deconvolution and Identification System (AMDIS) software [40] and normalized as percentages of the total chromatographic areas under consideration. The data analysis has been previously described in [22]. Also, in this case, analyses were repeated three times and the relative standard deviation was always below $10 \%$.

\section{Results and discussion \\ Physical properties and mass loss}

Table 2 presents the determined physical properties and mass losses of the experimental oak wood samples, including the reference wood and the samples after deposition in the monitoring stations: SP1 (wet peat environment) and SP4 (water-filled trench).

An increase in the time of sample burial led to a slight increase in wood porosity $(\mathrm{P})$. This is likely due to both the decomposition of cell walls and the extraction of water-soluble wood components. In the case of the samples in SP4, the extraction of substances soluble in weak alkaline conditions might also be a cause to consider. The increase in wood porosity is directly related to the slight increase in the maximum water content (MWC) and to the slight decrease in the basic density (BD) (Fig. 1). After 2 years of burial in SP1, the value for MWC was lower and the value for $\mathrm{BD}$ was higher than those observed for 
Table 1 Holocellulose and lignin pyrolysis products sorted into categories

\begin{tabular}{|c|c|c|c|}
\hline Category & Holocellulose pyrolysis products & Category & Lignin pyrolysis products \\
\hline Furans & $\begin{array}{l}\text { 2-Hydroxymethylfuran } \\
\text { 3-Hydroxymethylfuran } \\
\text { 2-Furancarboxylic acid } \\
\text { 2,3-Dihydrofuran-2,3-diol } \\
\text { 2-Furyl-hydroxymethylketone } \\
\text { 5-Hydroxymethyl-2-furaldehyde }\end{array}$ & Monomers & $\begin{array}{l}Z \text {-and E-coniferyl alcohols } \\
Z \text {-and E-sinapyl alcohols }\end{array}$ \\
\hline Pyranones & $\begin{array}{l}\text { 3-Hydroxy-(2H)-pyran-2-one } \\
\text { 3-Hydroxy-(4H)-pyran-4-one } \\
\text { 5-Hydroxy-2H-pyran-4(3H)-one } \\
\text { 3-Hydroxy-6-methyl-(2H)-pyran-2-one } \\
\text { 2-Methyl-3-hydroxy-(4H)-pyran-4-one } \\
\text { 2-Hydroxymethyl-2,3-dihydropyran-4-one } \\
\text { 3,5-Dihydroxy-2-methyl-(4H)-pyran-4-one (2TMS) } \\
\text { 2-Hydroxymethyl-5-hydroxy-2,3-dihydro-(4H)-pyran-4-one } \\
\text { 2,3,5-Trihydroxy-4H-pyran-4-one }\end{array}$ & Altered side chain & $\begin{array}{l}\text { Guaiacol } \\
\text { 4-Methylguaiacol } \\
\text { 4-Ethylguaiacol } \\
\text { Syringol } \\
\text { 4-Vinylguaiacol } \\
\text { 4-Methylsyringol } \\
\text { 4-Ethylsyringol } \\
\text { 4-Vinylsyringol } \\
\text { Z-, E- and iso-eugenol } \\
\text { Z-and E-4-isopropenylsyringol } \\
\text { Vanillylpropanol } \\
\text { Syringylpropanol }\end{array}$ \\
\hline Hydroxybenzenes & $\begin{array}{l}\text { 1,2,3-Trihydroxybenzene } \\
\text { 1,2,4-Trihydroxybenzene }\end{array}$ & Oxidised & $\begin{array}{l}\text { Vanillin } \\
\text { Acetovanillone } \\
\text { Syringaldehyde } \\
\text { Acetosyringone } \\
\text { Coniferylaldehyde } \\
\text { Sinapylaldehyde } \\
\text { 4-Hydroxy benzoic acid } \\
\text { Vanillic acid } \\
\text { Syringic acid } \\
\text { 3,4-Dihydroxy-5-methoxy benzoic acid }\end{array}$ \\
\hline Cyclopentenones & $\begin{array}{l}\text { 1-Hydroxy-1-cyclopenten-3-one } \\
\text { 2-Hydroxy-1-cyclopenten-3-one } \\
\text { Z-and E-2,3-dihydroxy-cyclopent-2-enone } \\
\text { 2-Hydroxymethyl-3-methy-2-cyclopentenone } \\
\text { 1-Hydroxy-2-methyl-1-cyclopenten-3-one } \\
\text { 1-Methy-2-hydroxy-1-cyclopenten-3-one } \\
\text { 2-Methyl-3-hydroxymethyl-2-cyclopentenone } \\
\text { Z- and E-2,3-dihydroxy-cyclopent-2-enone } \\
\text { 3-Hydroxy-2-hydroxymethyl-2-cyclopentenone } \\
\text { 3-Hydroxy-2-(hydroxymethyl) cyclopenta-2,4-dienone }\end{array}$ & $\begin{array}{l}\text { Demethylated/dem- } \\
\text { ethoxylated }\end{array}$ & $\begin{array}{l}\text { 4-Methylcatechol } \\
\text { 4-Ethylcatechol } \\
\text { 3-Methoxy-1,2-benzenediol } \\
\text { 5-Methyl-3-methoxy-1,2-benzenediol } \\
\text { 5-Vinyl-3-methoxy-1,2-benzenediol } \\
\text { 5-Propyl-3-methoxy-1,2-benzenediol } \\
\text { Coumaryl alcohol (2 TMS) } \\
\text { Trihydroxy cinnamic alcohol (3TMS) } \\
\text { 3,4-Dihydroxy cinnamyl alcohol (3TMS) } \\
\text { Z-2-methoxy-3,4-dihydroxy cinnamic } \\
\text { alcohol (3TMS) } \\
\text { E-2-Methoxy-3,4-dihydroxy cinnamic } \\
\text { alcohol (3TMS) }\end{array}$ \\
\hline Anhydrosugars & $\begin{array}{l}\text { 1,4:3,6-dianhydro-a-D-glucopyranose } \\
\text { 1,4-anydro-D-galactopyranose } \\
\text { 1,6-anydro-D-galactopyranose } \\
\text { 1,4-anydro-D-galactopyranose } \\
\text { 1,6-anydro-beta-D-glucopyranose } \\
\text { 1,4-anhydro-D-glucopyranose } \\
\text { 1,6-anydro-beta-D-glucofuranose }\end{array}$ & & \\
\hline
\end{tabular}

the reference samples. In general, however, the changes in the MWC, BD and P of wood buried for 2-10 years were relatively small in both monitoring stations. These changes indicate only a very slight degree of degradation of the oak wood used in this experiment, but they could also be considered as being within the compositional variability of wood.

Regarding the mass loss (ML), an almost regular increasing trend during the period of sample deposition was observed (Fig. 1). Initially (after 2 years), the ML was significantly lower in the case of SP1 than SP4. Nevertheless, very similar results in ML were observed after 10 years of wood deposition, showing that the dynamics of this slight degradation might be different in the two environments examined, but the final outcome is very similar.

It should be noted that the ML in the reference samples was $1.0 \% \pm 0.2 \%$. Similarly to the samples buried in the Biskupin site, the reference sample was soaked in water for 10 days before the beginning of 
Table 2 Physical properties (mean \pm standard deviation) of the oak wood samples

\begin{tabular}{|c|c|c|c|c|c|}
\hline $\begin{array}{l}\text { Period of deposition } \\
\text { (years) }\end{array}$ & $\begin{array}{l}\text { Place of sample } \\
\text { deposition }\end{array}$ & $\begin{array}{l}\text { MWC } \\
\text { Maximum water content } \\
(\%)\end{array}$ & $\begin{array}{l}\text { BD } \\
\text { Basic density } \\
\left(\mathrm{kg} \mathrm{m}^{-3)}\right.\end{array}$ & $\begin{array}{l}\text { P } \\
\text { Porosity (\%) }\end{array}$ & $\begin{array}{l}\text { ML } \\
\text { Mass loss (\%) }\end{array}$ \\
\hline 0 & Reference & $97 \pm 9$ & $616 \pm 35$ & $57.6 \pm 2.2$ & $1.0 \pm 0.2$ \\
\hline 2 & $\mathrm{SP} 1^{\mathrm{a}}$ & $94 \pm 7$ & $631 \pm 29$ & $57.1 \pm 1.8$ & $1.3 \pm 0.2$ \\
\hline 4 & & $99 \pm 10$ & $610 \pm 37$ & $58.6 \pm 2.3$ & $2.3 \pm 0.4$ \\
\hline 6 & & $97 \pm 10$ & $620 \pm 37$ & $58.1 \pm 2.3$ & $2.4 \pm 0.2$ \\
\hline 8 & & $103 \pm 9$ & $600 \pm 34$ & $59.5 \pm 2.1$ & $3.2 \pm 0.4$ \\
\hline 10 & & $100 \pm 7$ & $610 \pm 25$ & $58.8 \pm 1.6$ & $3.6 \pm 0.4$ \\
\hline 2 & $\mathrm{SP} 4^{\mathrm{b}}$ & $100 \pm 9$ & $605 \pm 35$ & $58.8 \pm 2.2$ & $3.5 \pm 0.7$ \\
\hline 4 & & $102 \pm 8$ & $601 \pm 31$ & $59.1 \pm 1.8$ & $2.6 \pm 0.3$ \\
\hline 6 & & $104 \pm 7$ & $596 \pm 28$ & $59.4 \pm 1.6$ & $2.7 \pm 0.4$ \\
\hline 8 & & $99 \pm 9$ & $611 \pm 33$ & $58.6 \pm 2.0$ & $3.2 \pm 0.7$ \\
\hline 10 & & $102 \pm 11$ & $601 \pm 39$ & $59.2 \pm 2.5$ & $3.8 \pm 0.5$ \\
\hline
\end{tabular}

a Wet peat environment

${ }^{\mathrm{b}}$ Water-sediment at the bottom of water-filled archaeological trench

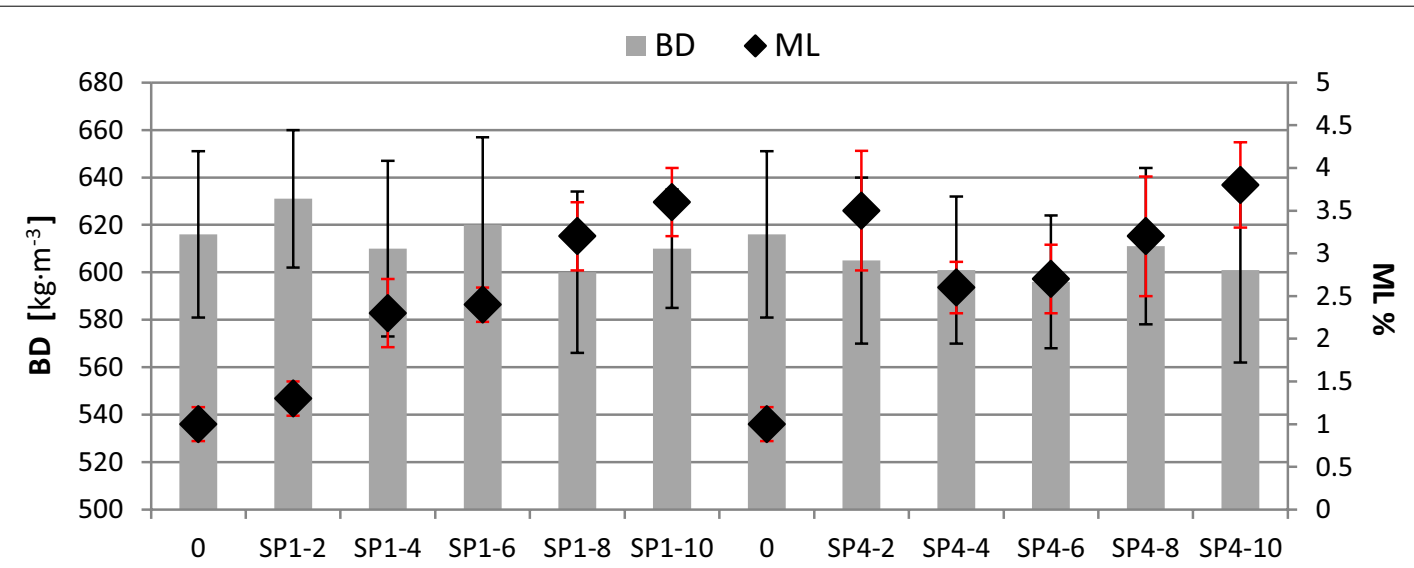

Fig. 1 Mass loss (ML) and basic density (BD) results

the experiment (see "Samples" section). This ML was therefore not due to wood decomposition, but rather to the extraction of water-soluble substances during the above-mentioned process. This means that all the other samples underwent a comparable mass loss before they were buried in the site. As a consequence, the ML of the wood left in the site, which was actually caused by both biotic and abiotic damage and by further extraction of water-soluble substances during the burial period, was about 1\% lower than the values shown in Table 2.

This result underlines the importance of always referring the values to those obtained for reference samples, and further proves the very low level of degradation of these samples after 10 years of burial in the monitoring stations. Note that these samples might have undergone a counter-effect to the decomposition and to water and alkali extractive action. In fact, various chemical compounds dissolved in water in both environments may have entered the wood structure, thus resulting in an increase in sample mass and a corresponding relative reduction in mass loss. This phenomenon is virtually impossible to be accounted for numerically but should be considered in the interpretation of the results. Overall, in this case too, the results can be considered as being within the variability of the composition of the material and measurement errors.

\section{Chemical composition}

The changes undergone by wood components in all the analysed samples after 2, 4, 6, 8 and 10 years of burial in both SP1 and SP4 stations were investigated by wet 
chemical analysis, infrared spectroscopy and analytical pyrolysis.

The determination of changes in waterlogged wood chemical composition is usually based on the comparison of the results obtained from degraded and unaltered wood of the same species [41]. The parameters that are often used for this purpose are the $\mathrm{H} / \mathrm{L}$ ratio between the content of polysaccharides and lignin, and the $\mathrm{C} / \mathrm{L}$ ratio between the content of cellulose and lignin [16, 42]. More detailed information on the chemical changes occurring in the biopolymers present in the wood structure can be obtained by examining the molecular profile of lignin and polysaccharide pyrolysis products and, in particular, when the holocellulose and lignin pyrolysis products are categorized [22].

\section{Classical wet chemical analysis}

In order to quantitatively evaluate the content of wood components-cellulose, lignin, ashes and extractives-in the samples, different classical analytical methods were used, based on the separation and determination of the weight of the separated wood components (see "Methods" section). Holocellulose (sum of cellulose and hemicelluloses) content was calculated by subtracting the lignin, ashes and extractives content from the total mass. The results obtained for oak wood in SP1 and SP4 after 2, 4, 6, 8 and 10 years of burial are listed in Table 3.

The content of holocellulose in the reference sample was $69.9 \%$, of which $38.5 \%$ was cellulose, and the quantity of lignin accounted for $25.5 \%$.

The content of holocellulose during the 10-year burial in both monitoring stations decreased, the content of lignin relatively increased, and the content of cellulose was almost stable.

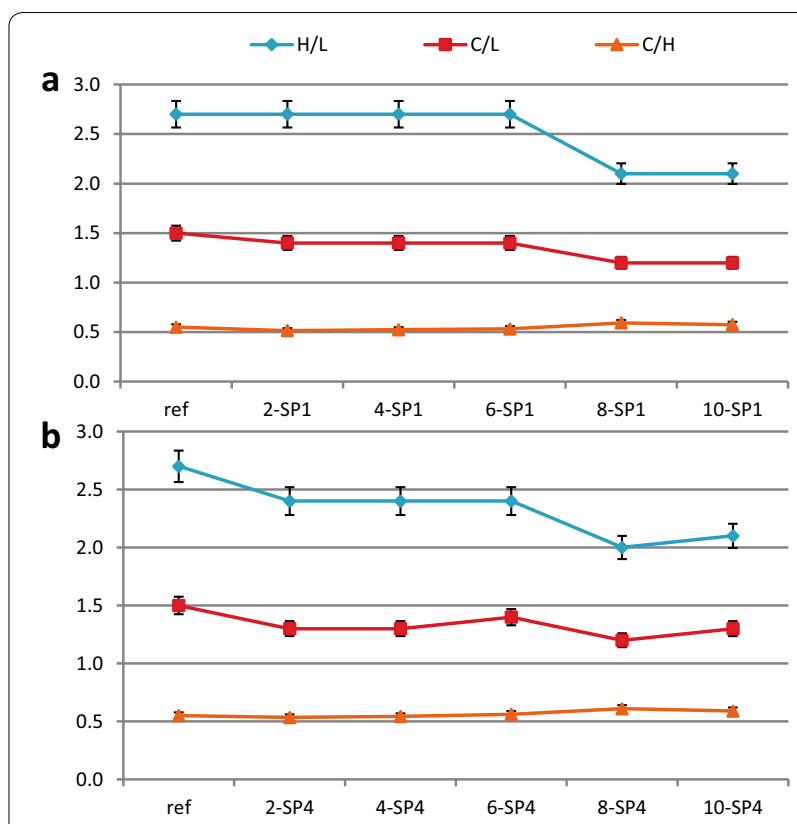

Fig. $2 \mathrm{H} / \mathrm{L}, \mathrm{C} / \mathrm{L}$ and $\mathrm{C} / \mathrm{H}$ ratios obtained from wet chemical analysis of oak reference wood (ref) and the wood samples after 2, 4, 6, 8 and 10 years of burial in: a SP4 (water sediment), and $\mathbf{b}$ SP4 (wet peat)

Some ratios were calculated between holocellulose and lignin $(\mathrm{H} / \mathrm{L})$, cellulose and lignin $(\mathrm{C} / \mathrm{L})$, as well as cellulose and holocellulose $(\mathrm{C} / \mathrm{H})$ (Fig. 2). A decrease in the $\mathrm{H} / \mathrm{L}$ ratio was observed during the burial period in both the monitoring stations, especially after 8 years of burial. It also appeared that the wet peat (SP1) led to slightly lower changes in the H/L than the water sediment (SP4) in the initial period of the experiment. However, the final outcome was again very similar. These results agree with the changes observed for the physical properties. Since

Table 3 Wet chemical analysis results expressed as percentage of oven-dry wood mass (mean \pm standard deviation)

\begin{tabular}{|c|c|c|c|c|c|c|}
\hline $\begin{array}{l}\text { Burial period } \\
\text { (years) }\end{array}$ & Burial place & Holocellulose $\%^{\mathrm{a}}$ & Cellulose $\%$ & Lignin \% & Extractives \% & Ash \% \\
\hline 0 & Reference & 69.9 & $38.5 \pm 0.2$ & $25.5 \pm 0.2$ & $3.5 \pm 0.1$ & $1.1 \pm 0.1$ \\
\hline 2 & SP1 & 70.1 & $36.1 \pm 0.4$ & $26.4 \pm 0.5$ & $2.4 \pm 0.1$ & $1.1 \pm 0.1$ \\
\hline 4 & & 70.3 & $36.9 \pm 0.5$ & $26.5 \pm 0.3$ & $1.8 \pm 0.1$ & $1.4 \pm 0.1$ \\
\hline 6 & & 70.4 & $37.5 \pm 0.3$ & $26.0 \pm 0.2$ & $2.1 \pm 0.8$ & $1.5 \pm 0.1$ \\
\hline 8 & & 64.8 & $38.5 \pm 0.2$ & $31.9 \pm 0.2$ & $1.8 \pm 0.1$ & $1.5 \pm 0.1$ \\
\hline 10 & & 65.2 & $37.5 \pm 0.2$ & $31.1 \pm 0.8$ & $1.9 \pm 0.3$ & $1.8 \pm 0.1$ \\
\hline 2 & SP4 & 67.9 & $36.3 \pm 0.2$ & $28.4 \pm 0.5$ & $2.6 \pm 0.1$ & $1.1 \pm 0.1$ \\
\hline 4 & & 68.3 & $37.1 \pm 0.5$ & $27.9 \pm 0.5$ & $2.5 \pm 0.1$ & $1.3 \pm 0.1$ \\
\hline 6 & & 68.1 & $38.3 \pm 0.2$ & $27.8 \pm 0.2$ & $2.0 \pm 0,8$ & $1.3 \pm 0.1$ \\
\hline 8 & & 65.2 & $39.8 \pm 0.3$ & $31.8 \pm 0.3$ & $1.8 \pm 0.0$ & $1.2 \pm 0.1$ \\
\hline 10 & & 65.9 & $38.9 \pm 0.3$ & $31.1 \pm 0.5$ & $1.5 \pm 0.0$ & $1.5 \pm 0.1$ \\
\hline
\end{tabular}

\footnotetext{
a The standard deviation is not reported, as these values are calculated as a subtraction and are not obtained from an actual measurement
} 
the ratio between cellulose and lignin $(\mathrm{C} / \mathrm{L})$ decreased during the experiment, and the ratio between cellulose and holocellulose $(\mathrm{C} / \mathrm{H})$ increased (Fig. 2), while the cellulose content remained almost stable over time (Table 3), the polysaccharide fraction that was affected more at the end of the 10 years of burial turned out to be hemicellulose.

The changes in water-soluble extractives and ashes followed expected trends, such as an increase in ashes, as a result of penetration of mineralized water into the more and more porous wood structure; and a decrease in extractives, as a result of leaching in the waterlogged environment.

\section{FT-IR}

The FTIR spectra (fingerprint region $2000-800 \mathrm{~cm}^{-1}$ ) of the oak wood reference and the samples deposited in wet peat (SP1) are shown in Fig. 3.

The FTIR spectra of all samples, including those deposited in the water-filled archaeological trench, did not show any remarkable difference. Only slight changes were noticed between the spectrum acquired for the reference oak wood sample and those of the aged samples. The bands in the fingerprint region $\left(2000-800 \mathrm{~cm}^{-1}\right)$ are affected by the contribution of all wood components. Only some bands can be assigned to the single wood constituents. For example, some changes in the hemicellulose structure can be observed from the absorption band at $1730 \mathrm{~cm}^{-1}$ [43], which decreased in intensity during the period of natural degradation (from 2 to 10 years). This absorption band is attributed to $\mathrm{C}=\mathrm{O}$ stretching of acetyl and carbonyl groups, which are mostly present in hemicelluloses (xylan backbone) $[44,45]$. The observed decrease is natural, well known and was due to reduction reactions of the carbonyl functional group [46, 47]. Although it cannot be fully associated with a decrease in the content of hemicelluloses, it proves that there was a structural alteration of this wood component. The absorption band at $1503 \mathrm{~cm}^{-1}$ is assigned to lignin [43]. Its slight relative increase during the years of burial was an indication of the general small depletion of carbohydrates. Another absorption band considered in this study was that at $897 \mathrm{~cm}^{-1}$, assigned to $\mathrm{C}-\mathrm{H}$ deformation in polysaccharides (holocellulose).

To better understand the changes that occurred in oak wood during the monitoring period, following Pandey [43], some ratios between areas of lignin- and carbohydrate-related absorption bands were calculated (1503/1730 and 1503/897). The results are presented in Fig. 4. A general increase in both the ratios 1503/1730 and 1503/897 was observed during burial. This confirmed that the contribution of lignin to IR absorption increased with respect to the carbohydrates, as a result of a small loss of carbohydrates during the deposition period. The loss of acetyl groups from xylans was also confirmed. Additionally, the ratio between the areas of the absorption bands at $1730 \mathrm{~cm}^{-1}$ and $897 \mathrm{~cm}^{-1}$, corresponding to hemicelluloses (acetyl groups) and cellulose respectively, decreased during the monitoring period. This highlighted the slower alteration of cellulose with respect to hemicelluloses in the analyzed samples during

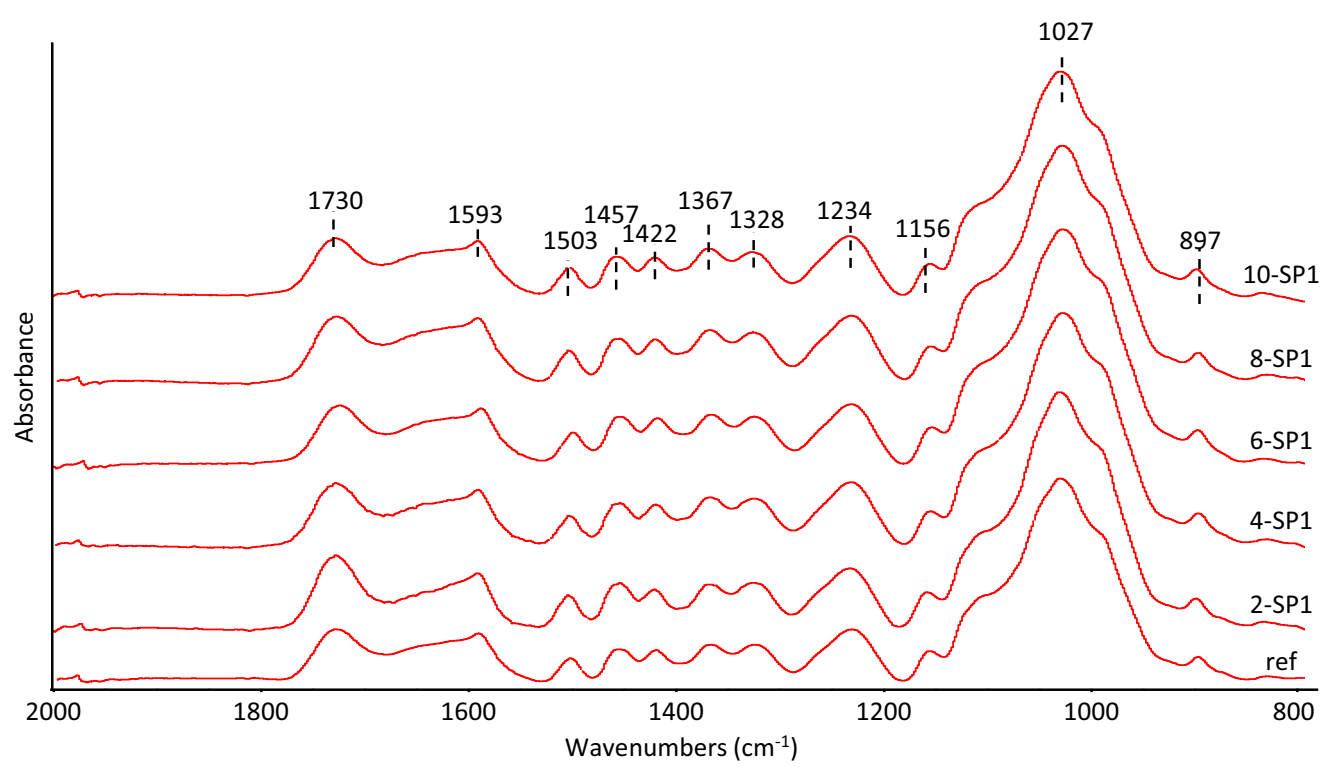

Fig. 3 FTIR-ATR spectra of the oak reference wood (ref) and of the wood samples after 2, 4, 6, 8 and 10 years of burial in SP1 (wet peat) 


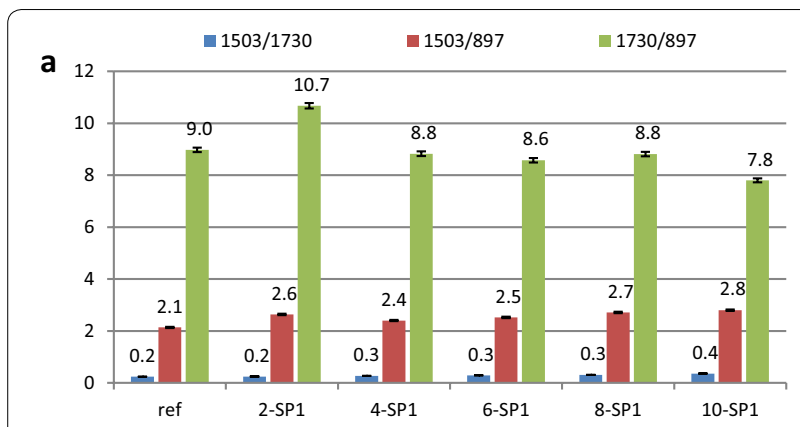

b

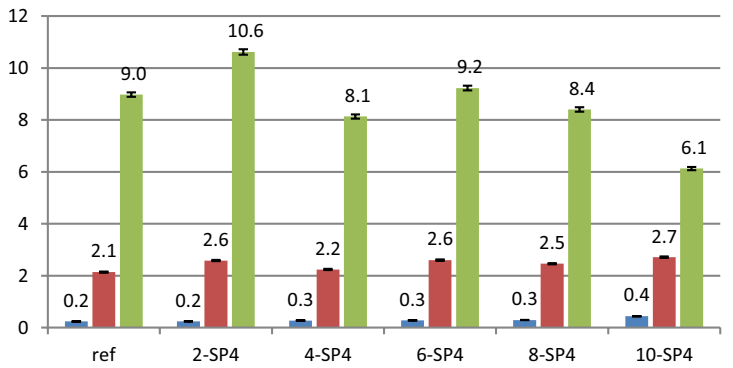

Fig. 4 Ratios between areas of FTIR absorption bands attributed to lignin and carbohydrates (1503/1730, 1503/897), and hemicellulose and cellulose (1730/897) obtained for the oak reference wood (ref) and for the wood samples after 2, 4, 6, 8 and 10 years of burial in a SP1 (wet peat) and b SP4 (water sediment)

natural ageing. When comparing the two monitoring environments, similar trends were observed. However, in the water sediment (Fig. 4b) acetyl groups underwent a more significant decay, as observed from the lower values of the $1730 / 897$ ratio.

\section{Analytical pyrolysis Py-GC/MS}

Analytical pyrolysis does not differentiate between the pyrolysis products derived from cellulose and hemicelluloses, as the thermal degradation mostly produces the same pyrolysis products from the two types of polysaccharides. This means that the $\mathrm{Py}-\mathrm{GC} / \mathrm{MS}$ method applied in this study cannot reveal the details of the chemical changes observed specifically in cellulose and hemicelluloses, but only in the overall polysaccharide fraction (holocellulose).

Figure 5 presents the pyrolytic profile of the reference oak wood sample. In the chromatograms obtained for all the wood samples, the pyrolysis products were attributed to holocellulose $(\mathrm{H})$ and lignin $(\mathrm{L})$. They were then classified into categories as reported in Table 1 and calculations based on chromatographic areas were performed as explained in [22]. The results are presented in Figs. 6, 7.

As far as holocellulose is concerned (Fig. 6), the PyGC/MS results did not show any significant change in the chemical composition after 10 years of burial. A comparison of the relative amounts of holocellulose pyrolysis products after 10 years of burial and those in sound oak wood revealed a high level of similarity: cyclopentenones and anhydrosugars showed similar percentages (about $36 \%$ ), as well as pyranones (ca. 17\%), hydroxybenzenes (7\%), and furans (4\%). Nevertheless, there were some mid-term fluctuations in the pyrolysis profile of the samples, in particular the SP1 ones.

The changes in the relative amounts of anhydrosugars and cyclopentenones are likely related to the polysaccharides structure and their polymerisation degree [48, 49]. However, it was difficult to associate the fluctuations observed in these particular samples to specific phenomena that had occurred during burial. Nevertheless, some structural and chemical changes related to holocellulose have already been highlighted by other techniques, such as minor loss of sugar oligomers and loss of acetyl groups.

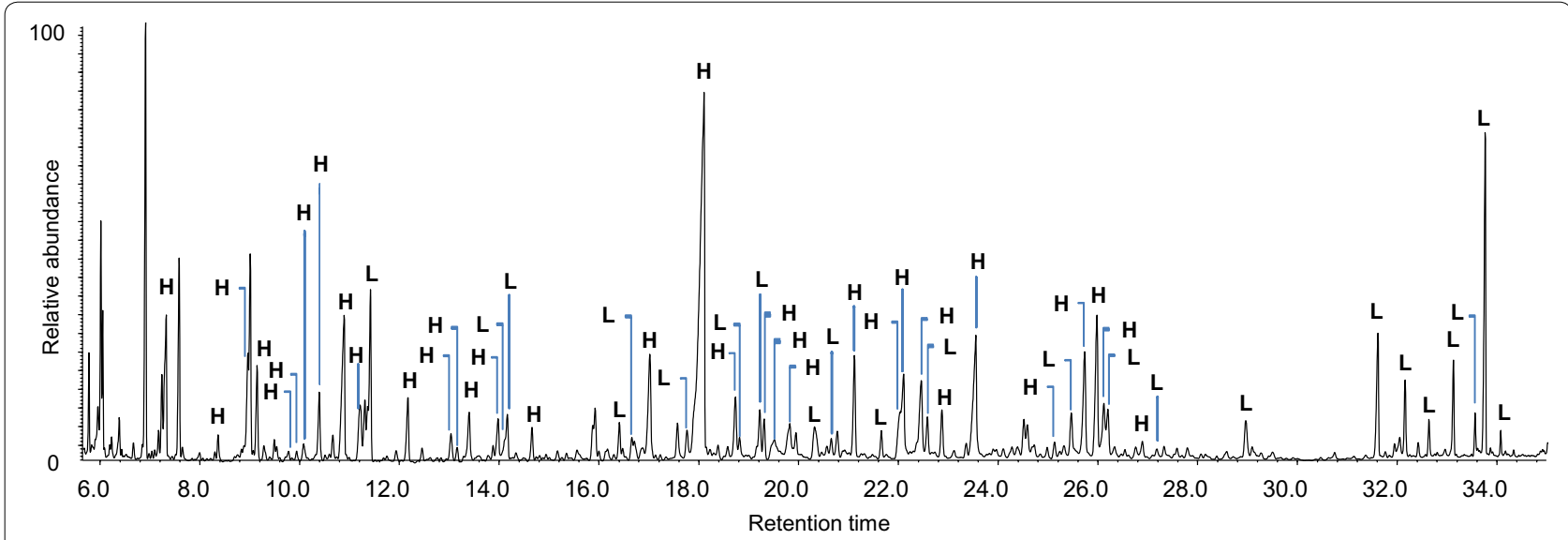

Fig. 5 Pyrolytic profile of the sound oak wood reference sample. Holocellulose $(H)$ and lignin $(L)$ pyrolysis products are indicated 


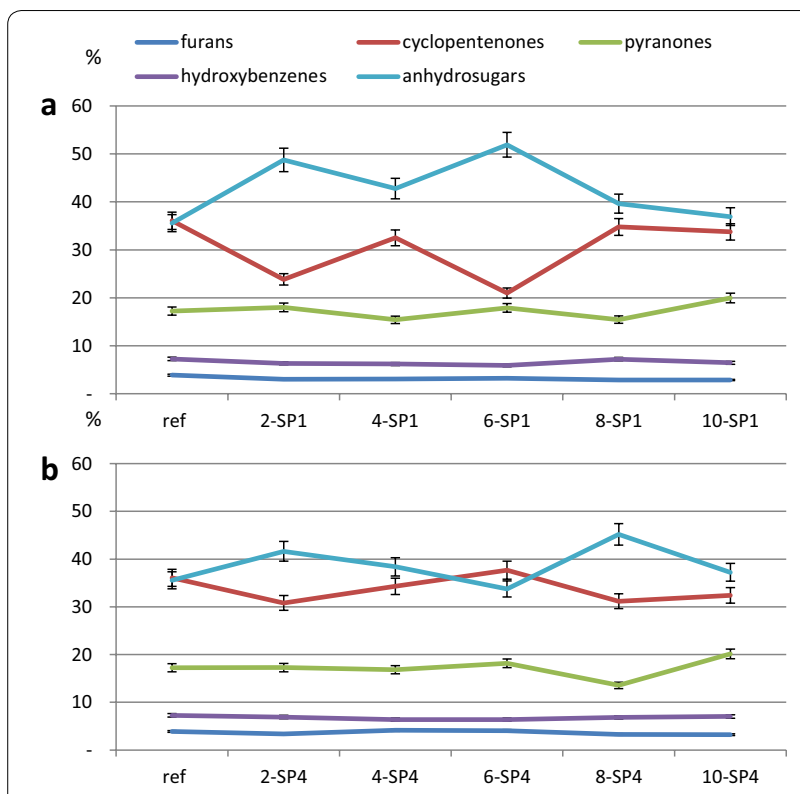

Fig. 6 Percentage distribution of the categories of holocellulose pyrolysis products in the samples from a SP4 (water sediments) and $\mathbf{b}$ SP1 (wet peat) after 2, 4, 6, 8 and 10 years of burial
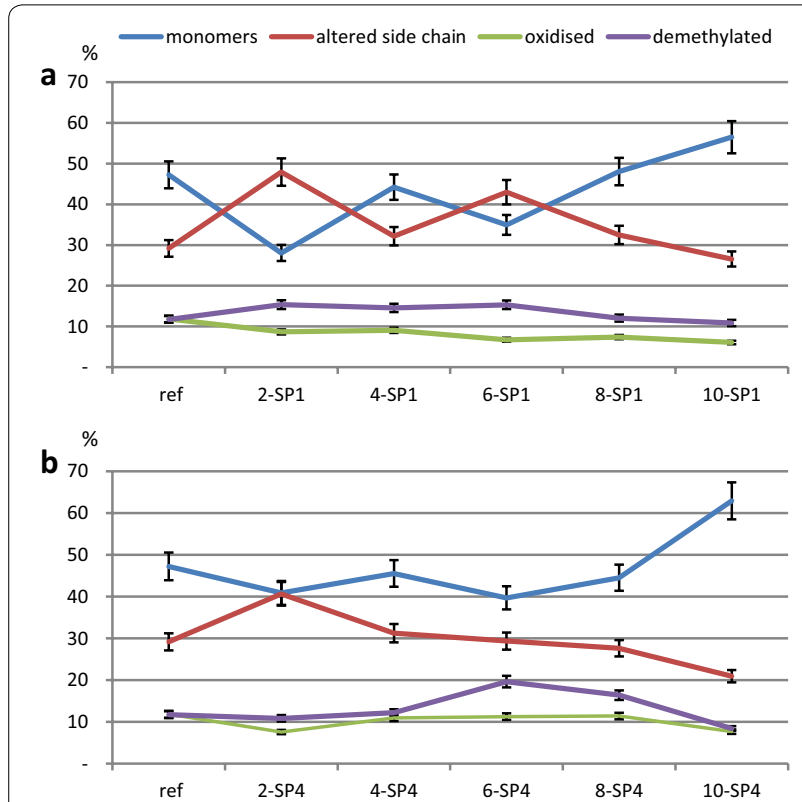

Fig. 7 Percentage distribution of the categories of lignin pyrolysis products in the samples from a SP4 (water sediments) and $\mathbf{b}$ SP1 (wet peat) after 2, 4, 6, 8 and 10 years of burial

The pyrolysis results did not fully reflect these processes, probably due to the compositional variability of wood.

On a different note, the differences in the burial environments, such as the $\mathrm{pH}$ in SP1 being close to neutral (6.8-7.2) and the $\mathrm{pH}$ in SP4 being more alkaline
(7.6-7.8), or the conductivity in SP1 being higher (960$\left.1890 \mu \mathrm{S} \mathrm{cm}^{-1}\right)$ than in SP4 (550-1190 $\left.\mu \mathrm{S} \mathrm{cm}^{-1}\right)$, due to a higher abundance of salts in the soil than in water [30], can be hypothesized as main causes for the slight differences observed in the pyrolysis results between the two stations. It is in fact known that slight alkaline conditions, although favourable to wood preservation [50, 51], can affect the hydrolysis of carbohydrates [52].

As far as lignin is concerned (Fig. 7), the pyrolysis profiles also showed fluctuations in the mid-term of the experiment, especially for the monomers and alteredside-chain pyrolysis products. These were interpreted as variations in the pyrolysis yield due to changes in the intermolecular linkages among lignin and the polysaccharides [42, 43]. In fact, pyrolysis products, such as monomers and altered-side-chain compounds, are indicators of the alteration of these linkages [22].

The outcome of these processes after 10 years appeared very similar for the two stations and was represented by an increased abundance of lignin monomers among the pyrolysis products. This may be related to the slight solubilisation and loss of carbohydrates previously observed. Free from connections with sugars, lignin changes its pyrolytic behaviour and forms a higher relative amount of monomers during pyrolysis.

Again, the mid-term fluctuations are more difficult to explain and are probably partially due to the compositional variability of wood.

\section{Conclusions}

The results showed that 10 years of burial in the monitoring stations led to relatively small changes in the physical properties of fresh oak wood examined in the experiment. The slight mass loss observed, and the slight increase in maximum water content and wood porosity, as well as the slight decrease in basic density, can be partly attributed to a minimal decomposition of cell walls, and partly to the extraction of water-soluble substances.

The chemical analysis revealed a loss in hemicellulose content and alterations in the hemicellulose fraction were also highlighted by the decrease in absorption associated with the $\mathrm{C}=\mathrm{O}$ stretching of acetyl and carbonyl groups in the FTIR spectra. Additionally, a slower alteration of cellulose compared to hemicelluloses during natural ageing was noticed. Py-GC/MS analysis did not reveal any significant alteration in the chemical composition of lignin and holocellulose during the experiment.

When comparing the two monitoring environments, acetyl groups underwent a more significant alteration in the water sediment than in the peat environment. The rate of the detected alterations was slightly different 
in the two stations in the initial period of burial. However, the final condition of the wood after 10 years was very similar in both burial environments. The results are in good agreement with other observations obtained on the same samples. In particular, few sporadic anatomical changes and a good level of resistance from fungal attack have been reported.

Sound wood is not the perfect model to simulate the behaviour and stability of degraded archaeological wood. This was also proved by parallel experiments in which archaeological wood was reburied in the same monitoring stations, showing a higher level of degradation compared to the results obtained in this experiment. Nevertheless, this study supports the conservation strategy based on in situ preservation of Biskupin remains, and proves that the wet environment at the Biskupin site is suitable for a safe conservation of wood material, at least when the initial level of degradation is not critical, which is the case for most archaeological wood found in the site.

\begin{abstract}
Abbreviations
AMDIS: Automated Mass Spectral Deconvolution and Identification System; ATR: Attenuated total reflection; BD: Basic density; C: Cellulose; El: Electron impact; FTIR: Fourier transform infrared spectroscopy; H: Holocellulose; HMDS: 1,1,1,3,3,3-hexamethyldisilazane; L: Lignin; ML: Mass loss; MWC: Maximum water content; P: Wood porosity; Py-GC/MS: Pyrolysis coupled with gas chromatography and mass spectroscopy; SD: Standard deviation; SEM: Scanning electron microscopy; SP1: Monitoring station in the archaeological site of Biskupin corresponding to a wet peat environment; SP4: Monitoring station in the archaeological site of Biskupin corresponding to a water environment at the bottom of the sediment layer of a water-filled archaeological trench;TAPPI: Technical Association of the Pulp and Paper Industry.
\end{abstract}

\section{Acknowledgements}

Not applicable.

\section{Authors' contributions}

JJL: Methodology, writing-original draft preparation, data interpretation, review and editing; DT: Investigation, formal analysis, data interpretation, review and editing, MZ: Conceptualization, methodology, investigation, data interpretation, writing-original draft preparation, review and editing, LB: Conceptualization, investigation, FM: Data interpretation, writing-reviewing and editing, MPC: Supervision, reviewing and editing. All authors read and approved the final manuscript.

\section{Funding}

This research was carried out within bilateral project Italy-Poland "Wet archaeological wooden material: a multi-analytical approach for decay diagnosis", under the Agreement CNR-Italy/PAS-Poland (2017-2019) and University of Pisa research project PRA_2018_26"Advanced analytical pyrolysis to study polymers in renewable energy, environment, cultural heritage".

\section{Availability of data and materials}

All data generated or analyzed during this study are included in this published article. More information is available from the corresponding author on reasonable request.

\section{Competing interests}

The authors declare that they have no competing interests.

\section{Author details}

${ }^{1}$ Department of Chemistry and Industrial Chemistry, University of Pisa, via G. Moruzzi 13, 56124 Pisa, Italy. ${ }^{2}$ Institute of Chemical Wood Technology, Faculty of Wood Technology, Poznań University of Life Sciences, Poznan, Poland. ${ }^{3}$ Department of Conservation, Archaeological Museum in Biskupin, Biskupin, Poland. ${ }^{4}$ Present Address: Department of Conservation and Scientific Research, Freer Gallery of Art and Arthur M Sackler Gallery, Smithsonian Institution, 1050 Independence Ave SW, Washington, DC 20560, USA.

Received: 12 December 2019 Accepted: 28 April 2020

Published online: 07 May 2020

\section{References}

1. Williams J, Howarth C, Panter I, Davies G. Preserving archaeological remains. Swindon: Historic England; 2016.

2. Wahlgren KH. Reburial and analyses of archaeological remains. Studies on the effect of reburial on archaeological materials performed in Marstrand, Sweden 2002-2005. The RAAR project. Public Archaeol. 2007;6(4):252-5.

3. Gregory D, Matthiesen $\mathrm{H}$, editors. Editorial. Proceedings of the 4th international conference: preserving archaeological remains in situ (PARIS $\left.{ }_{4}\right)$ 2012 23-26 May 2011; Copenhagen, Denmark: Taylor \& Francis.

4. UNESCO. Convention on the protection of the underwater cultural heritage. In: The General conference of the United Nations Educational, Scientific and Cultural Organisation 31st session; 5 October-3 November 2001; Paris. 2001

5. Ważny T. Dendrochronology of Biskupin-absolute dating of the Early Iron Age settlement. Bull Pol Acad Sci Biol Sci. 1994;42(3):283-9.

6. Babiński L, et al. Stan i perspektywy zachowania drewna biskupinskiego. In: Biskupin AM, editor. Biskupin. 2009.

7. Lucejko JJ, Modugno F, Ribechini E, del Río JC. Characterisation of archaeological waterlogged wood by pyrolytic and mass spectrometric techniques. Anal Chim Acta. 2009;654:26-34.

8. Hocker E, Almkvist G, Sahlstedt M. The Vasa experience with polyethylene glycol: a conservator's perspective. J Cult Herit. 2012;13(3):S175-82.

9. Bell LS, Lee Thorp JA, Elkerton A. The sinking of the Mary Rose warship: a medieval mystery solved? J Archaeol Sci. 2009;36(1):166-73.

10. Hoffmann P. To be and to continue being a Cog: the conservation of the Bremen Cog of 1380. Int J Naut Archaeol. 2001;30(1):129-40.

11. Babiński L, Fejfer M, Prądzyński W. Environmental monitoring at the Lusatian culture settlement in Biskupin, Poland. J Wetl Archaeol. 2007;7:51-72.

12. Piotrowski W, Zajączkowski W. Protecting Biskupin by an artificial barrier. News WARP. 1993;14:7-11.

13. Jensen P, Gregory DJ. Selected physical parameters to characterize the state of preservation of waterlogged archaeological wood: a practical guide for their determination. J Archaeol Sci. 2006;33(4):551-9.

14. Blanchette RA. A review of microbial deterioration found in archaeological wood from different environments. Int Biodeterior Biodegrad. 2000:46(3):189-204.

15. Nilsson T, Rowell R. Historical wood-structure and properties. J Cult Herit. 2012;13(3):S5-9.

16. Łucejko JJ, Modugno F, Ribechini E, Tamburini D, Colombini MP. Analytical instrumental techniques to study archaeological wood degradation. Appl Spectrosc Rev. 2015;50(7):584-625.

17. Pizzo B, Pecoraro E, Alves A, Macchioni N, Rodrigues JC. Quantitative evaluation by attenuated total reflectance infrared (ATR-FTIR) spectroscopy of the chemical composition of decayed wood preserved in waterlogged conditions. Talanta. 2015;131:14-20.

18. Giachi G, Bettazzi F, Chimichi S, Staccioli G. Chemical characterisation of degraded wood in ships discovered in a recent excavation of the Etruscan and Roman harbour of Pisa. J Cult Herit. 2003:4(2):75-83.

19. Kostrzewski J. Osada bagienna w Biskupinie w pow. żnińskim. In: Kostrzewski J, Lubicz-Niezabitowski E, Jaroń B, editors. Osada bagienna w Biskupinie w pow żnińskim Tymczasowe sprawozdanie z prac wykopaliskowych Instytutu Prehistorycznego UP w latach 1934 i 1935. Poznań. 1936. p. 1-20.

20. Konopelko-Bielecki H. Badania nad korozja biskupińskiego drewna wykopaliskowego oraz jego wlasciwosciami fizycznymi, mechanicznymi i strukturalnymi. Poznań: University of Poznań; 1951. 
21. Ważny J. Deterioration of ancient wood in Biskupin archaeological excavations. Material und Organismen Beiheft. 1976;3:53-62.

22. Tamburini D, Łucejko JJ, Zborowska M, Modugno F, Prądzyński W, Colombini MP. Archaeological wood degradation at the site of Biskupin (Poland): wet chemical analysis and evaluation of specific Py-GC/MS profiles. J Anal Appl Pyrolysis. 2015;115:7-15.

23. Gajewska J, Jacak P, Babinski L. Influence of anoxic condition on the composition of microorganisms colonized a contemporary wood samples in archaeological site in Biskupin. Ecol Chem Eng A. 2011;11(2):183-90.

24. Babiński L, Zborowska M, Fabisiak E, Prądzyński W. Are the wooden remains of the Lusatian culture settlement at Biskupin safe? Decomposition of archaeological oak wood samples during a 10-year experiment. Archaeol Anthropol Sci. 2019;11(12):6583-94.

25. Sandak A, Sandak J, Babiński L, Pauliny D, Riggio M. Spectral analysis of changes to pine and oak wood natural polymers after short-term waterlogging. Polym Degrad Stab. 2014;99:68-79.

26. Łucejko JJ, Mattonai M, Zborowska M, Tamburini D, Cofta G, Cantisani E, et al. Deterioration effects of wet environments and brown rot fungus Coniophora puteana on pine wood in the archaeological site of Biskupin (Poland). Microchem J. 2018;138:132-46.

27. Tamburini D, Cartwright CR, Cofta G, Zborowska M, Mamoňová M. Distinguishing the signs of fungal and burial-induced degradation in waterlogged wood from Biskupin (Poland) by scanning electron microscopy. Microsc Microanal. 2018;24(2):163-82.

28. Standard E. Durability of wood and wood-based products - testing and classification of the durability to biological agents of wood and woodbased materials. 2016.

29. Babiński L, Fabisiak E, Zborowska M, Michalska D, Prądzyński W. Changes in oak wood buried in waterlogged peat: shrinkage as a complementary indicator of the wood degradation rate. Eur J Wood Wood Prod. 2019;77(4):691-703.

30. Babinski L, Fejfer M. Zmiany wybranych parametrów środowiska na stanowisku 4 w Biskupinie w latach 2003-2013. In: Nowaczyk S, Grossman A, Piotrowski W, editors. IV Sprawozdanie Biskupińskie. IV. Biskupin: Muzeum Archeologiczne w Biskupinie; 2015. p. 311-27.

31. Macchioni N, Pecoraro E, Pizzo B. The measurement of maximum water content (MWC) on waterlogged archaeological wood: a comparison between three different methodologies. J Cult Herit. 2018;30:51-6.

32. Pizzo B, Giachi G, Fiorentino L. Evaluation of the applicability of conventional methods for the chemical characterization of waterlogged archaeological wood. Archaeometry. 2010;52(4):656-67.

33. Hedges Jl. The chemistry of archaeological wood. In: Rowell RM, Barbour RJ, editors. Archaeological wood. Advances in chemistry. Washington: American Chemical Society; 1990. p. 111-40.

34. TAPPI, inventorAcid Insoluble lignin in wood and pulp T $222 \mathrm{om}-06.360$ Lexington AM, New York 17, NY, USA. 2006.

35. Sakuno T, Schniewind AP. Adhesive qualities of consolidants for deteriorated wood. J Am Inst Conserv. 1990;29(1):33-44.

36. TAPPI, inventorSolvent extractives of wood and pulp, Test Method T 204 cm-17. 360 Lexington AM, New York 17, NY, USA. 2007.

37. TAPPI, inventorAsh in wood, pulp, paper and paperboard: combustion at $525^{\circ}$ C. T 211 om-07. 360 Lexington AM, New York 17, NY, USA. 2007.
38. Tamburini D, Łucejko JJ, Pizzo B, Mohammed MY, Sloggett R, Colombini MP. A critical evaluation of the degradation state of dry archaeological wood from Egypt by SEM, ATR-FTIR, wet chemical analysis and Py(HMDS)GC-MS. Polym Degrad Stab. 2017;146:140-54.

39. Fabbri D, Chiavari G. Analytical pyrolysis of carbohydrates in the presence of hexamethyldisilazane. Anal Chim Acta. 2001;449(1-2):271-80.

40. Tobias K. 2004. http://www.amdis.net/.

41. Rowell RM, Barbour RJ. Archaeological wood properties, chemistry, and preservation. In: Rowell RM, Barbour RJ, editors. Washington: American Chemical Society; 1990.

42. Zborowska M, Babiński L, Gajewska J, Waliszewska B, Prądzyński W. Physical and chemical properties of contemporary pine wood (Pinus sylvestris L.) in conditions of a wet archaeological site in Biskupin. Folia Forestalia Pol. 2007;38(B):13-26.

43. Pandey KK, Pitman AJ. FTIR studies of the changes in wood chemistry following decay by brown-rot and white-rot fungi. Int Biodeterior Biodegrad. 2003;52(3):151-60.

44. Fackler K, Stevanic Jasna S, Ters T, Hinterstoisser B, Schwanninger $M$, Salmén L. FT-IR imaging microscopy to localise and characterise simultaneous and selective white-rot decay within spruce wood cells. Holzforschung. 2011;65:411-20.

45. Temiz A, Terziev N, Jacobsen B, Eikenes M. Weathering, water absorption, and durability of silicon, acetylated, and heat-treated wood. J Appl Polym Sci. 2006;102(5):4506-13.

46. Ganne-Chédeville C, Jääskeläinen A-S, Froidevaux J, Hughes M, Navi P. Natural and artificial ageing of spruce wood as observed by FTIR-ATR and UVRR spectroscopy. Holzforschung. 2012;66:163-70.

47. Lionetto F, Del Sole R, Cannoletta D, Vasapollo G, Maffezzoli A. Monitoring wood degradation during weathering by cellulose crystallinity. Materials. 2012;5(10):1910-22.

48. Mattonai M, Tamburini D, Colombini MP, Ribechini E. Timing in analytical pyrolysis: py(HMDS)-GC/MS of glucose and cellulose using online micro reaction sampler. Anal Chem. 2016;88(18):9318-25.

49. Moldoveanu SC. Analytical pyrolysis of polymeric carbohydrates. In: Coleman D, Price BF, editors. Analytical pyrolysis of natural organic polymers, vol. 20. Amsterdam: Elsevier Science; 1998. p. 217-316.

50. Kibblewhite M, Tóth G, Hermann T. Predicting the preservation of cultural artefacts and buried materials in soil. Sci Total Environ. 2015;529:249-63.

51. Caneva G, Nugari MP, Salvadori O, Getty Conservation I. Plant biology for cultural heritage: biodeterioration and conservation. Los Angeles: Getty Conservation Institute; 2008.

52. Tamburini D, Łucejko JJ, Zborowska M, Modugno F, Cantisani E, Mamoňová $M$, et al. The short-term degradation of cellulosic pulp in lake water and peat soil: a multi-analytical study from the micro to the molecular level. Int Biodeterior Biodegrad. 2017;116:243-59.

\section{Publisher's Note}

Springer Nature remains neutral with regard to jurisdictional claims in published maps and institutional affiliations.

\section{Submit your manuscript to a SpringerOpen ${ }^{\odot}$ journal and benefit from:}

- Convenient online submission

- Rigorous peer review

- Open access: articles freely available online

- High visibility within the field

- Retaining the copyright to your article

Submit your next manuscript at springeropen.com 